\title{
Ruminal Fermentation and Amino Acid Flow in Holstein Steers Fed Whole Cottonseed with Elevated Concentrations of Free Fatty Acids in the Oil
}

\author{
H. M. Sullivan, ${ }^{1, \star}$ J. K. Bernard, ${ }^{2}$ and H. E. Amos ${ }^{1}$ \\ ${ }^{1}$ Department of Animal and Dairy Science, The University of Georgia, Athens 30602 \\ ${ }^{2}$ Department of Animal and Dairy Science, The University of Georgia, Tifton 31793
}

\begin{abstract}
The influence of feeding whole cottonseed (WCS) containing elevated concentrations of free fatty acids (FFA) in the oil on ruminal fermentation and amino acid (AA) flow to the abomasum was evaluated in a $4 \times 4$ Latin square trial. Four ruminally and abomasally cannulated Holstein steers were fed diets containing $12.5 \%$ of dry matter as WCS with concentrations of 8.0, 11.3, 14.7 , or $18.0 \%$ FFA in the oil. Intake, ruminal digestibility, and flow to the abomasum of dry matter, organic matter, and acid detergent fiber were not affected by FFA level of WCS. Intake of neutral detergent fiber and total kilograms of neutral detergent fiber digested in the rumen were similar for all treatments. Ruminal neutral detergent fiber digestibility was lower for 8 and $14.7 \%$ FFA, resulting in a cubic effect on flow to the abomasum. Ruminal $\mathrm{pH}$, molar proportions of isobutyrate, and total branched-chain volatile fatty acids (VFA) decreased linearly, whereas molar proportions of acetate and acetate:propionate ratio increased linearly as FFA in WCS increased. Total VFA were lower, and molar proportions of propionate were higher, for 8 and $14.7 \%$ FFA, resulting in a cubic effect. Intake of $\mathrm{N}$, total $\mathrm{N}$ flow, and nonmicrobial $\mathrm{N}$ flow to the abomasum were similar among treatments. Flow of microbial $\mathrm{N}$ was lower for the $11.3 \%$ FFA treatment, resulting in a quadratic response. Only nonsignificant differences were observed in AA flow to the abomasum. Results of this trial indicate that WCS with FFA up to $18 \%$ may result in small changes in rumen fermentation.
\end{abstract}

(Key words: whole cottonseed, free fatty acid, ruminal fermentation, amino acid flow)

Abbreviation key: FA = fatty acid, IADF = indigestible ADF, $\mathbf{M N}=$ microbial N, WCS = whole cottonseed.

Received June 14, 2004.

Accepted September 13, 2004.

Corresponding author: J. K. Bernard; e-mail: jbernard@tifton. uga.edu.

*Current address: MSC 3AE, P.O. Box 30003, Las Cruces, NM 88003

\section{INTRODUCTION}

In normal years, the concentration of FFA in the oil of whole cottonseed (WCS) rarely exceeds $12 \%$. However, when tropical storms delay cotton harvest, the hot, humid conditions often lower the quality of cotton fiber and seed. Whole cottonseed with $>12 \%$ FFA are considered to be off-quality as defined by the National Cottonseed Products Association (1997) and are typically sold as livestock feed. Limited data exist on the implications of feeding WCS with higher than normal concentrations of FFA, but recent research indicated that feeding WCS with up to $12 \%$ FFA in the oil to high-producing dairy cattle does not significantly alter nutrient intake, milk yield, or milk composition (Sullivan et al., 2004).

High levels of dietary unsaturated fatty acids (FA) can be toxic to certain rumen microorganisms and can coat fiber particles, preventing fibrolytic bacteria from attaching, which subsequently depresses fiber digestion (MacLeod and Buchanan-Smith, 1972; Eastridge and Firkins, 1991). Jenkins (1993) reported that the level of unsaturated FFA in the rumen might be the determining factor in disruption of normal rumen fermentation. Because oilseeds contain high concentrations of unsaturated FA, increased concentrations of FFA in WCS could negatively affect fiber digestion by increasing the rate of FFA release from the seed (Martinez et al., 1991; DePeters and Cant, 1992). Previous research has demonstrated that increasing the rate of FFA release in soybeans by extrusion reduced $\mathrm{NDF}$ and $\mathrm{ADF}$ digestibility in mixed culture in vitro ruminal fermentations (Reddy et al., 1994).

It is well documented that feeding oilseed, such as WCS, tends to reduce milk protein percentage (Anderson et al; 1979; Smith, et al., 1981; DePeters et al., 1985). This decrease has been attributed to reduced microbial protein synthesis, which is a consequence of replacing ruminally fermentable carbohydrates with fat that does not provide energy in support of microbial protein synthesis; reduced microbial efficiency caused by growth uncoupling; and/or reduced protozoal and fibrolytic bacterial populations (Dunkley et al., 1977). High FFA WCS could also negatively affect membrane 
function and alter protozoal and fibrolytic bacterial populations. The objective of this trial was to determine the effects of feeding WCS with elevated concentrations of FFA in the oil on reticuloruminal fermentation and flow of nutrients to the abomasum in cannulated Holstein steers.

\section{MATERIALS AND METHODS}

Two lots of WCS containing 8 or $12 \%$ FFA were obtained from WCS warehouses in South Georgia and transported to Dairy Cattle Research Center at The University of Georgia in Athens. The FFA content of the WCS containing $12 \%$ FFA in the oil was elevated by increasing the moisture content to $20 \%$ for $72 \mathrm{~h}$ before air drying to approximately $90 \% \mathrm{DM}$. The FFA concentration in the WCS was determined according to NCPA (1997).

Four 350-kg Holstein steers fitted with ruminal (10.2 cm; Bar Diamond, Inc., Parma, ID) and abomasal (2.5 $\mathrm{cm}$ ) rubber cannulae were used in a $4 \times 4$ Latin squares to evaluate the effects of increasing FFA levels in WCS. Steers were cannulated and managed according to procedures approved by The University of Georgia Institutional Animal Care and Use Committee. Experimental periods were $14 \mathrm{~d}$ in length with $10 \mathrm{~d}$ for ration adjustment and $4 \mathrm{~d}$ for sample collection. Steers were housed in a tie stall barn and allowed to exercise for $2 \mathrm{~h} / \mathrm{d}$ in a dry lot.

Diets were formulated (Table 1) as described by Sullivan et al. (2004). The 2 lots of WCS were blended to provide $8,11.3,14.7$, and $18 \%$ FFA as outlined in Table 1 . The experimental diets were fed as a TMR twice daily at $110 \%$ of the previous day's intake. The amount of TMR offered and refused was recorded daily, and nutrient intake was calculated for $\mathrm{d} 7$ to 14 of each period. Samples of experimental diets and orts were collected daily on d 10 to 14 of each experimental period and composited by steer within period.

Ruminal and abomasal samples were collected on $\mathrm{d}$ 10 to 14 at 12 -h intervals. The sampling schedule was advanced $3 \mathrm{~h}$ each day. Ruminal fluid was collected and strained through 4 layers of cheesecloth, analyzed for $\mathrm{pH}$, and frozen for analysis. Rumen fluid samples were analyzed for VFA concentrations using a Varian 3400 gas chromatograph (Varian, Walnut Creek, CA). A composite ruminal fluid sample was formed by combining $25 \mathrm{~mL}$ from each collection time. Ruminal bacteria were isolated by centrifugation at $27,000 \times g$ using a KSB continuous flow system (Kendro Laboratory Products, Newton, CT). Bacterial isolates were lyophilized and stored for analyses. Abomasal samples were frozen for storage and later composited by steer within treatment and lyophilized.
Table 1. Ingredient and partial chemical composition of total mixed rations containing whole cottonseed (WCS) with increasing concentrations of free fatty acids (FFA) in the oil.

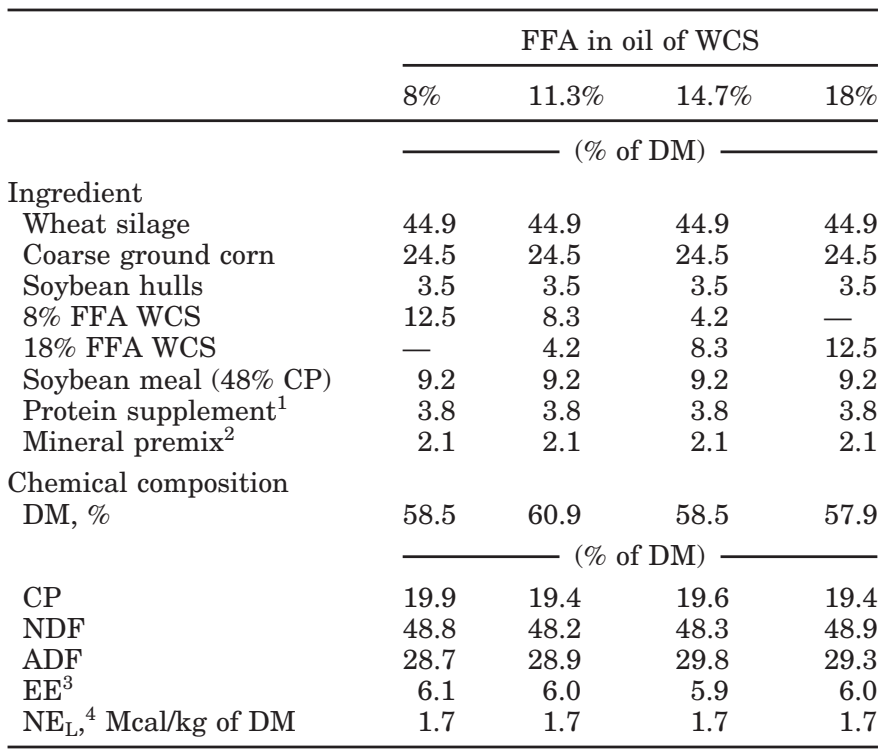

${ }^{1}$ Protein supplement was composed of $60 \%$ menhaden fish meal and $40 \%$ distillers grains with solubles.

${ }^{2}$ Premix contained $34.4 \% \mathrm{CP}$ from urea, $86.7 \%$ ash, $24.50 \% \mathrm{Ca}$, $3.68 \% \mathrm{P}, 1.27 \% \mathrm{Mg}, 0.08 \% \mathrm{~K}, 3.03 \% \mathrm{Na}, 4.60 \% \mathrm{Cl}, 0.31 \% \mathrm{~S}, 11.67$ ppm Co, 665 ppm Cu, 4622 ppm Fe, 58 ppm I, 2039 ppm Mn, 14.69 $\mathrm{ppm}$ Se, 293,370 IU/kg vitamin A, 117,350 IU/kg vitamin D, and 1466 IU/kg vitamin $\mathrm{E}$.

${ }^{3}$ Ether extract.

${ }^{4}$ Calculated using NRC (2000).

Diet, orts, and abomasal samples were ground to pass through a 1-mm screen using a Wiley mill (Authur H. Thomas, Philadelphia, PA) and analyzed for DM and ash (AOAC, 1984), NDF and ADF (Robertson and Van Soest, 1981), and total N (FP-528; Protein/Nitrogen Analyzer, Leco Corp. St. Joseph, MI). Ether extract of diet and ort samples was determined using Soxhlet extraction with petroleum ether (AOAC, 1984). Reticuloruminal nutrient digestibility and abomasal flow was calculated using indigestible ADF (IADF) as a marker (Henderson et al., 1985). The IADF of diet, ort, and abomasal samples was determined using a Daisy II 200 Rumen Fermentor (Ankom Technology Co., Fairport, NY).

Diet and abomasal samples were refluxed in $6 \mathrm{~N} \mathrm{HCl}$ under $99.9 \%$ pure $\mathrm{N}_{2}$ atmosphere for $24 \mathrm{~h}$ and then dried under reduced pressure (Amos et al., 1976). Hydrolysates were resuspended in a diluting buffer and analyzed for AA using a Beckman 1600 automated AA analyzer (Beckman Instruments, Inc., Fullerton, CA) with norleucine as an internal standard. Purine concentrations in the abomasal and bacterial isolate samples were determined using the procedure of Zinn and Owens (1986). The ratio of purines to microbial N (MN) 
was calculated for the bacterial isolate. This ratio was used to compute the percentage of bacterial $\mathrm{N}$ in abomasal samples and daily flow of MN was calculated. Apparent and true microbial efficiencies were determined using the following formulas:

$\mathrm{g}$ of microbial $\mathrm{N}$ flow/kg of OM digested

g microbial $\mathrm{N}$ flow/

( $\mathrm{kg}$ of $\mathrm{OM}$ digested - $\mathrm{kg}$ of microbial $\mathrm{N}$ flow).

Data were analyzed using the GLM procedure of SAS (1996). Using the model:

$$
\mathrm{Y}_{\mathrm{ijkl}}=\mathrm{m}+\mathrm{T}_{\mathrm{i}}+\mathrm{P}_{\mathrm{j}}+\mathrm{S}_{\mathrm{k}}+\mathrm{E}_{\mathrm{ijkl}},
$$

where $\mathrm{Y}_{\mathrm{ikkl}}=$ observation, $\mathrm{m}=$ population mean, $\mathrm{T}_{\mathrm{i}}=$ treatment effect ( $\mathrm{i}=1$ to 4$), \mathrm{P}_{\mathrm{j}}=$ period effect $(\mathrm{j}=1$ to $4), \mathrm{S}_{\mathrm{k}}=$ steer effect $(\mathrm{k}=1$ to 4$)$, and $\mathrm{E}=$ residual error. Rumen VFA and $\mathrm{pH}$ data were analyzed using PROC MIXED (SAS, 1996). The model included steer, treatment, period, hour, and the interaction of treatment and hour. Sampling time was included as a repeated measure, and steer within treatment was a random effect. When a significant interaction of treatment and sampling time was observed, the PDIF option was used for mean separation. Linear, quadratic, and cubic contrasts of FFA content were included in all analyses.

\section{RESULTS AND DISCUSSION}

The chemical compositions of the experimental diets were similar among treatment and reflected formulated values (Table 1). The chemical composition and FA profile of WCS fed are presented in Table 2 . The only notable difference in the 2 lots of WCS was slightly higher concentrations of C16:0 and C18:0 and slightly lower concentrations of C18:1 and C18:2 in the 18\% FFA WCS, which might have been variations between the 2 lots or could have been due to hydrogenation of the unsaturated bonds during formation of FFA.

There was no difference in DMI and OM intake among treatments, which averaged 9.4 and $8.7 \mathrm{~kg} / \mathrm{d}$, respectively (Table 3 ). This is in agreement with our previous trials in which lactating Holstein cows fed diets containing $12.5 \%$ WCS with 3 to $12 \%$ FFA consumed similar amounts of DM (Sullivan et al., 2004). However, Plascencia et al. (1999) reported increased intake of Holstein steers fed diets containing yellow grease with up to $42 \%$ FFA. There were no differences among treatments in $\mathrm{kg}$ of $\mathrm{DM}$ digested in the reticulorumen, apparent digestibility, or flow of DM to the abomasum. Flow of OM to the abomasum tended to decrease linearly $(P<0.07)$ with increasing FFA from
Table 2. Chemical composition of whole cottonseed (WCS) with increasing concentrations of free fatty acids (FFA) in the oil.

\begin{tabular}{lrr}
\hline & \multicolumn{2}{c}{ FFA in oil of WCS } \\
\cline { 2 - 3 } & $8 \%$ & $18 \%$ \\
\cline { 2 - 3 } & & \\
Ingredient & 88.8 & \\
DM & 26.7 & 88.0 \\
CP & 43.2 & 25.3 \\
NDF & 30.3 & 43.3 \\
ADF & 17.0 & 30.8 \\
EE ${ }^{1}$ & & 16.2 \\
& & \\
FA 2 profile & & \\
C10:0 & 0.1 & $<0.01$ \\
C14:0 & 0.7 & 0.6 \\
C16:0 & 22.0 & 23.1 \\
C16:1 & 0.5 & 0.5 \\
C18:0 & 1.0 & 2.4 \\
C18:1 & 16.0 & 14.6 \\
C18:2 & 54.3 & 52.6 \\
C20:0 & 0.2 & 0.3 \\
C18:3 & 0.2 & 0.2 \\
Other & 5.0 & 5.7 \\
\hline
\end{tabular}

${ }^{1}$ Ether extract.

${ }^{2}$ Fatty acid.

WCS. Intake of NDF showed a weak quadratic $(P<$ 0.13 ) trend. Total kilograms per day of NDF digested in the reticulorumen was similar for all treatments, but a cubic response $(P<0.03)$ was observed for NDF digestibility (\%) and NDF flow to the abomasum because of lower digestibility and greater flow to the abomasum for the 8 and $14.7 \%$ FFA WCS compared with 11.3 and the $18 \%$ FFA WCS. Intake of DM and NDF were numerically higher for the $8 \%$ FFA WCS diet, whereas kilograms of NDF digested were similar for all treatments. Therefore, the decreased NDF digestibility and increased NDF flow might be expected for the $8 \%$ FFA WCS treatment; however, the reasons for decreased NDF digestibility and increased NDF flow with the $14.7 \%$ FFA WCS diet are not clear. Reddy et al. (1994) reported decreased NDF digestion when extruded soybeans were added to in vitro ruminal fermentations. It should be noted that rupturing the soybean micelle by extrusion allows rapid exposure of microbes to FA, whereas the physical form of WCS causes more gradual dispersion of FA.

Intake of $\mathrm{ADF}$ tended $(P<0.10)$ to decrease linearly with increasing FFA in WCS. The kilograms of ADF digested in the reticulorumen decrease linearly $(P<$ $0.04)$ with increasing FFA in WCS. However, ADF digestibility was similar among treatments. Reddy et al. (1994) reported decreased in vitro ADF digestion for extruded soybeans; however, Keele et al. (1989) did not observe any change in ruminal ADF digestibility when 
Table 3. Effects of increasing levels of free fatty acids (FFA) in the oil from whole cottonseed (WCS) on nutrient intake, apparent reticuloruminal digestibility, and abomasal flow in Holstein steers.

\begin{tabular}{|c|c|c|c|c|c|c|c|c|}
\hline \multirow[b]{2}{*}{ Item } & \multicolumn{4}{|c|}{ FFA in oil of WCS } & \multirow[b]{2}{*}{ SE } & \multicolumn{3}{|c|}{ Contrast } \\
\hline & $8 \%$ & $11.3 \%$ & $14.7 \%$ & $18 \%$ & & Linear & Quadratic & Cubic \\
\hline \multicolumn{6}{|l|}{$\mathrm{DM}$} & \multicolumn{3}{|c|}{$\longrightarrow P$} \\
\hline $\begin{array}{l}\text { Intake, kg/d } \\
\text { Digestibility }\end{array}$ & 9.67 & 9.21 & 9.32 & 9.23 & 0.27 & 0.40 & 0.51 & 0.37 \\
\hline $\mathrm{kg} / \mathrm{d}$ & 3.36 & 3.11 & 3.12 & 3.07 & 0.22 & 0.46 & 0.67 & 0.55 \\
\hline$\%$ & 34.75 & 33.77 & 33.48 & 33.26 & 1.70 & 0.51 & 0.80 & 0.70 \\
\hline Flow to abomasum, kg/d & 6.31 & 6.11 & 6.20 & 6.16 & 0.16 & 0.70 & 0.61 & 0.50 \\
\hline \multicolumn{9}{|l|}{$\mathrm{OM}$} \\
\hline $\begin{array}{l}\text { Intake, kg/d } \\
\text { Digestibility }\end{array}$ & 8.93 & 8.57 & 8.6 & 8.57 & 0.23 & 0.33 & 0.65 & 0.35 \\
\hline $\mathrm{kg} / \mathrm{d}$ & 3.79 & 3.67 & 3.74 & 4.01 & 0.22 & 0.49 & 0.41 & 0.75 \\
\hline$\%$ & 42.48 & 42.57 & 43.30 & 47.00 & 2.06 & 0.18 & 0.41 & 0.42 \\
\hline Flow to abomasum, kg/d & 5.14 & 4.89 & 4.92 & 4.55 & 0.16 & 0.07 & 0.72 & 0.13 \\
\hline \multicolumn{9}{|l|}{$\mathrm{NDF}$} \\
\hline $\begin{array}{l}\text { Intake, kg/d } \\
\text { Digestibility }\end{array}$ & 4.83 & 4.47 & 4.51 & 4.58 & 0.12 & 0.29 & 0.13 & 0.32 \\
\hline $\mathrm{kg} / \mathrm{d}$ & 2.92 & 2.89 & 2.76 & 2.99 & 0.10 & 0.90 & 0.26 & 0.42 \\
\hline$\%$ & 60.46 & 64.47 & 61.20 & 65.28 & 1.21 & 0.16 & 0.93 & 0.03 \\
\hline Flow to abomasum, kg/d & 1.91 & 1.58 & 1.74 & 1.56 & 0.08 & 0.10 & 0.39 & 0.03 \\
\hline \multicolumn{9}{|l|}{$\mathrm{ADF}$} \\
\hline $\begin{array}{l}\text { Intake, kg/d } \\
\text { Digestibility }\end{array}$ & 2.75 & 2.71 & 2.55 & 2.63 & 0.07 & 0.10 & 0.38 & 0.77 \\
\hline $\mathrm{kg} / \mathrm{d}$ & 1.57 & 1.52 & 1.42 & 1.47 & 0.03 & 0.04 & 0.24 & 0.98 \\
\hline$\%$ & 57.09 & 56.09 & 55.69 & 55.89 & 1.22 & 0.71 & 0.76 & 0.77 \\
\hline Flow to abomasum, kg/d & 1.19 & 1.19 & 1.12 & 1.16 & 0.05 & 0.49 & 0.75 & 0.72 \\
\hline
\end{tabular}

WCS or extruded soybeans were included in diets fed to nonlactating Holstein cows. Also, Plascencia et al. (1999) reported similar digestibility of ADF for Holstein steers fed diets containing yellow grease with FFA concentrations up to $42 \%$. Only a single abomasal marker was utilized for this experiment (IADF), and the abomasal cannula used did not allow for complete removal of the abomasal contents, which could bias digestibility coefficients. However, NDF and ADF digestibility coefficients observed in this trial are in agreement with previous results at this location using multiple abomasal markers (chromic oxide and Co-EDTA) in steers eating a silage-based diet high in byproduct feeds (Bernard et al., 1988).

Table 4. Effect of increasing levels of free fatty acids (FFA) in the oil from whole cottonseed (WCS) on rumen VFA concentrations.

\begin{tabular}{|c|c|c|c|c|c|}
\hline \multirow[b]{2}{*}{ Item } & \multicolumn{4}{|c|}{ FFA in oil of WCS } & \multirow[b]{2}{*}{$\mathrm{SE}$} \\
\hline & $8 \%$ & $11.3 \%$ & $14.7 \%$ & $18.0 \%$ & \\
\hline $\mathrm{pH}^{\mathrm{a}}$ & 6.34 & 6.27 & 6.20 & 6.23 & 0.02 \\
\hline \multirow[t]{2}{*}{ Total VFA, ${ }^{\mathrm{b}} \mathrm{m} M$} & 99.20 & 104.30 & 97.83 & 100.87 & 2.00 \\
\hline & \multicolumn{4}{|c|}{ Molar proportion } & \\
\hline Acetate $^{\mathrm{c}}(\mathrm{A}), \%$ & 65.01 & 65.21 & 66.21 & 66.35 & 0.42 \\
\hline Propionate $^{\mathrm{b}}(\mathrm{P}), \%$ & 18.65 & 17.90 & 18.32 & 17.59 & 0.35 \\
\hline Butyrate, \% & 11.00 & 11.17 & 10.71 & 10.83 & 0.2 \\
\hline Isobutyrate $^{\mathrm{c}}, \%$ & 2.07 & 2.20 & 1.93 & 1.70 & 0.11 \\
\hline Isovalerate, $\%$ & 1.90 & 2.15 & 2.30 & 1.90 & 0.21 \\
\hline Valerate, $\%$ & 1.53 & 1.47 & 1.89 & 1.44 & 0.28 \\
\hline Total BCVFA, ${ }^{1, \mathrm{~d}} \%$ & 5.45 & 5.82 & 5.21 & 5.11 & 0.13 \\
\hline $\mathrm{A}: \mathrm{P}^{\mathrm{c}}$ & 3.52 & 3.66 & 3.76 & 3.81 & 0.08 \\
\hline
\end{tabular}

\footnotetext{
${ }^{1}$ Branched-chain VFA.

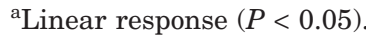

${ }^{\mathrm{b}}$ Cubic response $(P<0.05)$.

${ }^{\mathrm{c}}$ Linear response $(P<0.01)$.

${ }^{\mathrm{d}}$ Linear response $(P<0.005)$.
} 


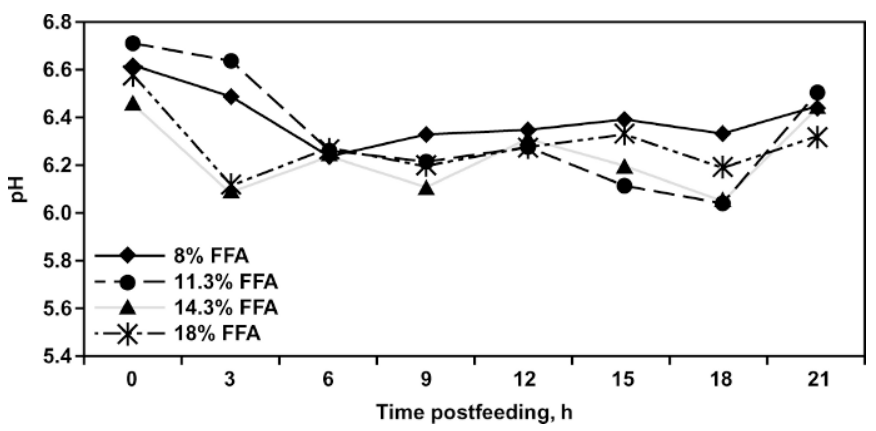

Figure 1. Effects of 8, 11.3, 14.7, and 18\% FFA whole cottonseed on rumen $\mathrm{pH}$ over time.

Average $\mathrm{pH}$ decreased linearly $(P<0.05)$ as FFA in WCS increased (Table 4). Rumen $\mathrm{pH}$ at $3 \mathrm{~h}$ postfeeding decreased linearly $(P<0.01)$ as the FFA concentration in WCS increased (Figure 1). Ruminal pH was lower $(P<0.05)$ at $18 \mathrm{~h}$ postfeeding for the diets containing WCS with 11.3 and $14.7 \%$ FFA compared with diets containing WCS with $8 \%$ FFA. There was no difference among treatments in $\mathrm{pH}$ at $6,9,12,15$, and $21 \mathrm{~h}$ after a.m. feeding. Maximum and minimum rumen $\mathrm{pH}$ was not affected by treatment.

Total ruminal VFA responded cubically $(P<0.05)$ with highest concentrations for $11.3 \% \mathrm{FFA}$, intermediate for 8 and 18\% FFA, and lowest for 14.7\% FFA (Table 4). Molar proportions of acetate $(P<0.01)$ and acetate:propionate ratio $(P<0.01)$ increased linearly, whereas isobutyrate $(P<0.01)$ and branched-chain VFA $(P<0.005)$ decreased linearly with increasing FFA from WCS. A cubic response $(P<0.05)$ was observed for molar proportions of propionate with higher concentrations for 8 and 14.7\% FFA compared with 11.3 and 18\% FFA. Molar proportions of butyrate were numerically lower with increasing dietary FFA level, but the difference was not significant. Molar proportions of isovalerate tended to respond quadratically $(P<0.13)$ with higher concentrations for 11.3 and $14.7 \%$ FFA WCS. Keele et al. (1989) reported that increasing levels of extruded soybeans decreased molar proportions of butyrate and increased molar proportions of propionate in in vitro fermentations. Avila et al. (2000) reported that supplemental fat in the diet from yellow grease or tallow tended to increase molar proportions of acetate, decrease butyrate, and increase the acetate:propionate ratio, whereas increasing dietary FFA by substituting tallow for yellow grease decreased molar proportions of isovalerate. Previous researchers have reported increased acetate:propionate ratio with the addition of WCS to the diet (Moody and Cook, 1961; Moody and Barnes, 1966). The changes in rumen VFA concentrations observed in this study are not indicative of reduced fiber digestion but may reflect small changes in microbial metabolism.

There was no difference among treatments in $\mathrm{N}$ intake, which averaged $286.1 \mathrm{~g} / \mathrm{d}$ (Table 5 ). Total $\mathrm{N}$ flow and percentage of $\mathrm{N}$ intake that flowed to the abomasum were not different among treatments. Previous research has shown decreased ruminal $\mathrm{N}$ digestibility, increased $\mathrm{N}$ flow, and decreased ruminal $\mathrm{NH}_{3}$ concentrations in response to supplemental lipid (Ikwuegbu and Sutton, 1982). Flow of MN was lowest for $11.3 \%$ FFA WCS, resulting in a quadratic response $(P<0.05)$. Flow of MN to the abomasum was highest for $8 \%$ FFA WCS, which corresponds with numerically higher DMI and apparent digestibility. The difference in MN flow among the 11.3, 14.7, and 18\% FFA WCS treatments cannot be easily accounted for by changes in energy availability to the microbes related to differences in

Table 5. Effects of increasing levels of free fatty acids (FFA) in the oil from whole cottonseed (WCS) on intake, passage, and digestibility of total $\mathrm{N}$ and nitrogenous compounds in the reticulorumen of Holstein steers.

\begin{tabular}{|c|c|c|c|c|c|c|c|c|}
\hline \multirow[b]{2}{*}{ Item } & \multicolumn{4}{|c|}{ FFA in oil of WCS } & \multirow[b]{2}{*}{$\mathrm{SE}$} & \multicolumn{3}{|c|}{ Contrast } \\
\hline & $8 \%$ & $11.3 \%$ & $14.7 \%$ & $18 \%$ & & Linear & Quadratic & Cubic \\
\hline & & & & & & & $-P$ & \\
\hline $\mathrm{N}$ intake, g/d & 296.77 & 279.83 & 280.34 & 287.36 & 7.74 & 0.48 & 0.17 & 0.57 \\
\hline \multicolumn{9}{|l|}{ Flow to abomasum } \\
\hline Total N, g/d & 293.71 & 280.71 & 282.35 & 289.47 & 8.08 & 0.80 & 0.26 & 0.75 \\
\hline$\%$ of $\mathrm{N}$ intake & 98.97 & 100.31 & 100.72 & 100.73 & 1.93 & 0.53 & 0.66 & 0.64 \\
\hline Microbial N, g/d & 93.29 & 72.42 & 79.32 & 80.14 & 4.27 & 0.20 & 0.04 & 0.07 \\
\hline$\%$ of $\mathrm{N}$ intake & 31.01 & 28.89 & 27.61 & 28.39 & 1.95 & 0.43 & 0.56 & 0.82 \\
\hline Nonmicrobial N, g/d & 200.42 & 208.29 & 203.03 & 209.33 & 9.87 & 0.70 & 0.94 & 0.53 \\
\hline$\%$ of $\mathrm{N}$ intake & 68.53 & 70.48 & 72.92 & 71.84 & 2.47 & 0.28 & 0.59 & 0.90 \\
\hline \multicolumn{9}{|c|}{$\begin{array}{l}\text { Microbial N synthesis efficiency, } \\
\text { g of N/kg OM digested }\end{array}$} \\
\hline Apparent & 23.02 & 25.09 & 20.78 & 21.29 & 1.39 & 0.12 & 0.61 & 0.51 \\
\hline True & 25.07 & 21.20 & 21.65 & 20.51 & 2.20 & 0.26 & 0.56 & 0.33 \\
\hline
\end{tabular}


Table 6. Estimated amino acid intake of steers fed diets containing increasing levels of free fatty acids (FFA) in the oil from whole cottonseed (WCS).

\begin{tabular}{|c|c|c|c|c|}
\hline \multirow[b]{2}{*}{ Item } & \multicolumn{4}{|c|}{ FFA in oil of WCS } \\
\hline & $8 \%$ & $11.3 \%$ & $14.7 \%$ & $18 \%$ \\
\hline & \multicolumn{4}{|c|}{$\longrightarrow(\mathrm{g}$ of $\mathrm{AA} / \mathrm{d})$} \\
\hline Thr & 51.9 & 51.3 & 47.8 & 46.5 \\
\hline Val & 6.8 & 3.7 & 3.8 & 3.7 \\
\hline Met & 23.1 & 22.4 & 19.7 & 20.1 \\
\hline Ile & 57.6 & 57.8 & 52.5 & 49.2 \\
\hline Leu & 111.4 & 107.2 & 99.3 & 92.1 \\
\hline Phe & 75.9 & 60.6 & 52.5 & 62.9 \\
\hline His & 32.7 & 43.8 & 49.7 & 28.3 \\
\hline Lys & 65.4 & 53.1 & 60.9 & 63.8 \\
\hline Arg & 52.9 & 69.9 & 68.4 & 72.9 \\
\hline Total EAA ${ }^{1}$ & 507.4 & 469.7 & 454.4 & 439.6 \\
\hline Tyr & 23.1 & 22.4 & 19.7 & 20.1 \\
\hline Cys & 43.2 & 40.1 & 33.8 & 33.8 \\
\hline Asp & 118.2 & 112.7 & 104.1 & 102.2 \\
\hline Glu & 215.3 & 192.0 & 183.7 & 183.3 \\
\hline Gly & 67.3 & 61.5 & 63.7 & 61.1 \\
\hline Ser & 64.4 & 57.8 & 55.3 & 57.4 \\
\hline Pro & 77.8 & 81.1 & 69.4 & 68.4 \\
\hline Ala & 91.3 & 104.4 & 92.8 & 80.2 \\
\hline NEAA & 507.4 & 469.6 & 454.4 & 439.6 \\
\hline Total AA & 1208.0 & 1141.7 & 1076.6 & 1046.1 \\
\hline
\end{tabular}

${ }^{1} \mathrm{EAA}=$ essential AA; NEAA $=$ nonessential AA.

DMI or apparent digestibility. Keele et al. (1989) reported decreased flow of MN to the duodenum when oilseeds were fed. However, Avila et al. (2000) reported increased MN flow when yellow grease $(2.90 \%$ FFA) was substituted for tallow (5.50\% FFA). Flow of non$\mathrm{MN}$ ( $\mathrm{g} / \mathrm{d}$ and \% of $\mathrm{N}$ intake) were not different among treatments. A weak linear trend $(P<0.12)$ was observed for apparent microbial efficiency, but true microbial efficiency was not affected by treatment. Several studies have reported improved microbial efficiency with supplemental fat in conjunction with decreased dietary protein deamination (Czerkawski et al., 1975; Ikwuegbu and Sutton, 1982; Jenkins and Palmquist, 1984; Boggs et al., 1987). Those researchers postulated that these results were due to an increase in the solids dilution rate and/or reduced $\mathrm{N}$ recycling caused by a decrease in protozoal populations. Murphy et al. (1987) reported apparent microbial efficiencies of $17.3 \mathrm{~g}$ of N/ $\mathrm{kg}$ of OM digested in lactating Swedish Red and White cows consuming approximately $14.5 \mathrm{~kg} / \mathrm{d}$ of a $40 \%$ concentrate, $60 \%$ hay diet. This efficiency increased to 26.6 $\mathrm{g}$ of N/kg of OM digested with the addition of $2 \mathrm{~kg} / \mathrm{d}$ of crushed rapeseed to the diet. The addition of increasing levels of FFA to the diet did not have a similar effect on MN yield or efficiency as fat addition. The only study available for comparison that utilized fats containing FFA (Avila et al., 2000) reported a nonsignificant decrease in apparent microbial efficiency from 27.6 to 20.1 $\mathrm{g}$ of $\mathrm{N} / \mathrm{kg}$ of OM digested as FFA in the diet increased when yellow grease was substituted for tallow in lactating dairy cows consuming $>23 \mathrm{~kg}$ of DM/d. These results are similar to the results of this study.

Intake of AA was estimated using the AA analysis of pooled diet samples (Table 6). Differences in AA intake among treatment were primarily due to differences in DM intake; however, numerical differences in several of the AA, including valine, histidine, and arginine, cannot be explained by differences in DMI alone. No significant differences were observed among treatments in flow of any of the measured AA in this study. There was a weak cubic effect $(P<0.18)$ observed for serine, glutamate, glycine, tyrosine, valine, and phenylalanine flow. A weak quadratic trend $(P<0.17)$ was observed for flow of total essential AA because of lower values for $11.3 \%$ FFA WCS compared with $8,14.7$, and $18 \%$ FFA WCS. Total nonessential AA flow tended ( $P$ $<0.11$ ) to decrease linearly with increasing FFA from WCS. There was no difference among treatments in total AA flow to the abomasum, which averaged 1234.39 g/d. Previous research (Sullivan et al., 2004) has shown differences in plasma AA levels in lactating cows fed diets containing WCS with up to $12 \%$ FFA in the oil. Lowered plasma EAA levels might be indicative of reduced EAA availability caused by less EAA flowing to the abomasum; however, no evidence of reduced EAA availability to the animal was observed in this study.

Concentrations of EE were similar among diets, so any changes in rumen metabolism would be expected to be related to FFA. There were small but significant changes in rumen fermentation, including kilograms of ADF digested, VFA production, ruminal $\mathrm{pH}$, and $\mathrm{MN}$ production. There was no indication of a drastic decrease in fiber digestion; however, there were small but significant changes in fiber digestibility. The proportion of acetate increased as FFA in WCS increased despite trends toward decreasing NDF and ADF intake. Small but significant changes in rumen microbial metabolism were indicated by changes in MN production and the shift in rumen VFA production.

Many of the effects observed were cubic or quadratic, and it is difficult to predict what impact these changes might have on lactating dairy cow production. Although there were changes in ruminal $\mathrm{N}$ metabolism, there was no effect of high FFA WCS on flow of lysine and methionine to the abomasum. Although there were numerical trends for the flow of essential and nonessential AA to the abomasum, total AA flow was similar for all treatments. It is unclear how these changes could affect AA balance in support of milk synthesis.

Whole cottonseed containing up to $18 \%$ FFA in the oil fed at up to $12.5 \%$ of DMI does not appear to depress DMI or drastically alter fiber digestion. Previous research has shown that feeding WCS with up to $12 \%$ 
Table 7. Grams of amino acids reaching the abomasum of Holstein steers fed diets containing increasing levels of free fatty acids (FFA) in the oil from whole cottonseed (WCS).

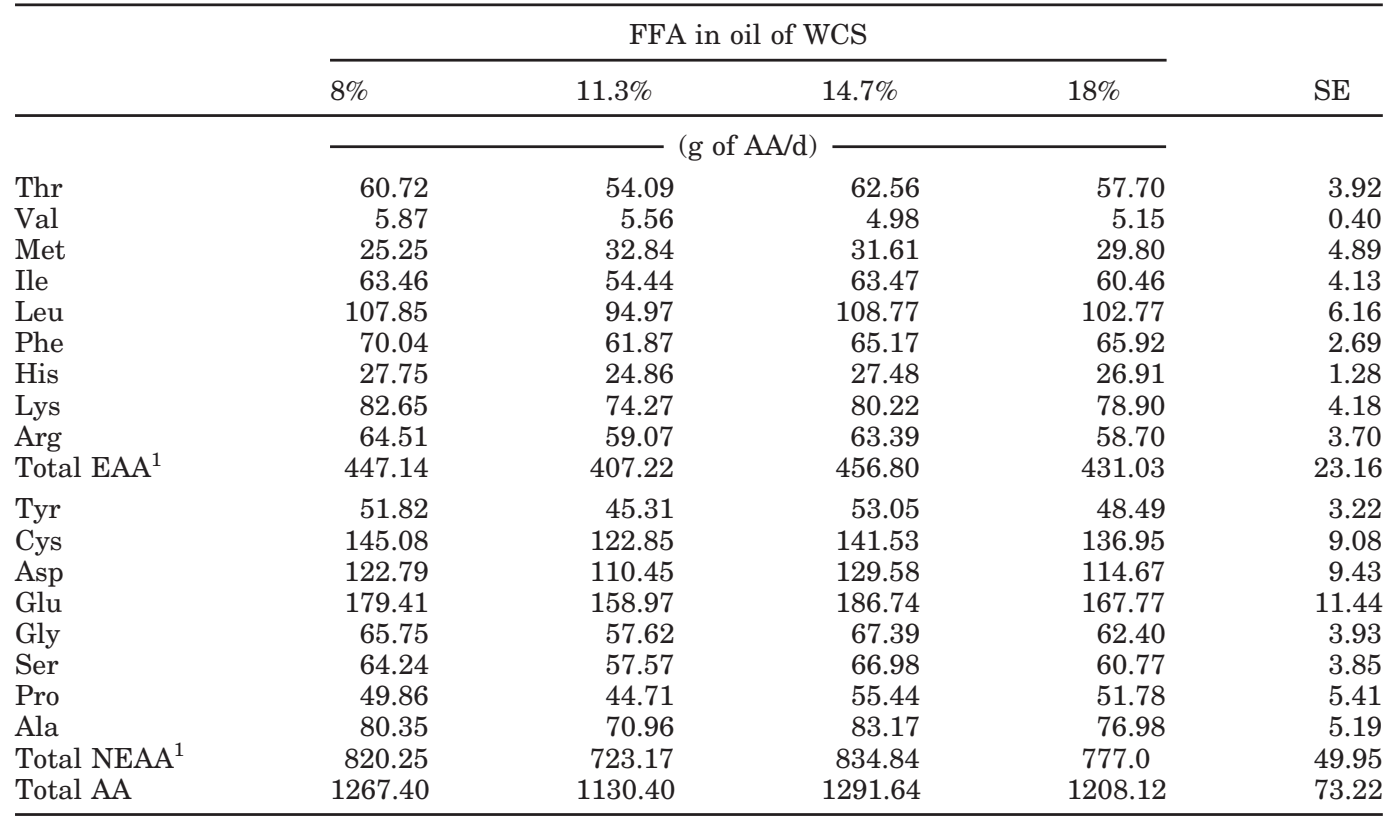

${ }^{1} \mathrm{EAA}=$ Essential AA; NEAA = nonessential AA.

${ }^{a}$ Linear response $(P<0.05)$.

${ }^{\mathrm{b}}$ Cubic response $(P<0.05)$.

'Linear response $(P<0.01)$.

${ }^{\mathrm{d}}$ Linear response $(P<0.005)$.

FFA in the oil does not negatively affect milk yield or composition of lactating dairy cows despite changes in plasma AA levels when WCS with $12 \%$ FFA was fed (Sullivan et al., 2004). Additional research is needed to determine the effect of feeding WCS with $>12 \%$ FFA on ruminal fermentation and performance of lactating dairy cows.

\section{ACKNOWLEDGMENTS}

Partial funding was provided by the Florida Milk Check-Off, Georgia Cotton Commission, and Cotton Incorporated. Appreciation is extended to D. W. Bell and Chickasha of Georgia for assistance in securing WCS supplies and to the employees at the University Dairy Farm in Athens, GA for assistance with animal care and feeding.

\section{REFERENCES}

Amos, H. E., J. Evans, and D. Burdick. 1976. Abomasal protein recovery and microbial synthesis in wethers fed high and low quality forage diets. J. Anim. Sci. 42:970-976.

Anderson, M. J., D. C. Adams, R. D. Lamb, and J. L. Walters. 1979. Feeding whole cottonseed to lactating dairy cows. J. Dairy Sci. 62:1098-1103.

Association of Official Analytical Chemists. 1984. Official Methods of Analysis. 14th ed. AOAC, Arlington, VA.
Avila, C. D., E. J. DePeters, H. Perez-Monti, S. J. Taylor, and R. A. Zinn. 2000. Influences of saturation ratio of supplemental dietary fat on digestion and milk yield. J. Dairy Sci. 83:1505-1509.

Bernard, J. K., H. E. Amos, and M. A. Froetschel. 1988. Influence of supplemental energy and protein on protein synthesis and crude protein reaching the abomasum. J. Dairy Sci. 71:2658-2669.

Boggs, D. L., W. G. Bergen, and D. R. Hawkins. 1987. Effects of tallow supplementation and protein withdrawal on ruminal fermentation, microbial synthesis, and site of digestion. J. Anim. Sci. 64:907-914

Czerkawski, J. W., W. W. Christie, G. Breckenridge, and M. L. Hunter. 1975. Changes in the rumen metabolism of sheep given increasing amounts of linseed oil in their diet. Br. J. Nutr. 34:25-44.

DePeters, E. J., and J. P. Cant. 1992. Nutritional factors influencing the nitrogen composition of bovine milk: A review. J. Dairy Sci. 75:2043-2070.

DePeters, E. J., S. J. Taylor, A. A. Franke, and A. Anguirre. 1985. Effects of feeding whole cottonseed on composition of milk. J. Dairy Sci. 68:897-902.

Dunkley, W. L., N. E. Smith, and A. A. Franke. 1977. Effects of feeding protected tallow on composition of milk and milk fat. J. Dairy Sci. 60:1863-1869.

Eastridge, M. L., and J. L. Firkins. 1991. Feeding hydrogenated fatty acids and triglycerides to lactating dairy cows. J. Dairy Sci. $74: 2610-2616$.

Henderson, S. J., H. E. Amos, and J. J. Evans. 1985. Influence of dietary protein concentration and degradability on milk production, composition, and ruminal protein metabolism. J. Dairy Sci. 68:2227-2257.

Ikwuegbu, O. A., and J. D. Sutton. 1982. The effect of varying the amount of linseed oil supplementation on rumen metabolism in sheep. Br. J. Nutr. 48:365-375.

Jenkins, T. C. 1993. Lipid metabolism in the rumen. J. Dairy Sci. 76:3851-3862. 
Jenkins, T. C., and D. L. Palmquist. 1984. Effect of fatty acids of calcium soaps on rumen and total nutrient digestibility of diary rations J. Dairy Sci. 67:978-986.

Keele, J. W., R. E. Roffler, and K. Z. Beyers. 1989. Ruminal metabolism in nonlactating cows fed whole cottonseed or extruded soybeans. J. Anim. Sci. 67:1612-1622.

MacLeod, G. L., and J. G. Buchanan-Smith. 1972. Digestibility of hydrogenated tallow, saturated fatty acids and soybean-supplemented diets by sheep. J. Anim. Sci. 35:890-895.

Martinez, N. E., J. DePeters, and D. L. Bath. 1991. Supplemental niacin and fat effects on milk composition of lactating Holstein cows. J. Dairy Sci. 74:202-210.

Moody, E. G., and W. J. Barnes. 1966. Cottonseed and oil in dairy rations at two roughage levels. J. Dairy Sci. 49(Suppl. 1):719. (Abstr.)

Moody, E. H., and A. P. Cook. 1961. Whole cottonseed in limited-fiber rations for dairy cattle. J. Dairy Sci. 44(Suppl. 1):1176. (Abstr.)

Murphy, M., P. Uden, D. L. Palmquist, and H. Wiktorsson. 1987. Rumen and total diet digestibilities in lactating cows fed diets containing full-fat rapeseed. J. Dairy Sci. 70:1572-1582.

National Cottonseed Products Association. 1997. Rules of the National Cottonseed Products Association, Inc. Natl. Cottonseed Products Assoc., Memphis, TN.
National Research Council. 2001. Nutrient Requirements of Dairy Cattle. 6th rev. ed. Natl. Acad. Sci., Washington, DC.

Plascencia, A. M. Estrada, and R. A. Zinn. 1999. Influence of free fatty acid content on the feeding value of yellow grease in finishing diets for feedlot cattle. J. Anim. Sci. 77:2603-2609.

Reddy, P. V., J. L. Morrill, and T. G. Nagaraja. 1994. Release of free fatty acids from raw or processed soybeans and subsequent effects on fiber digestibilites. J. Dairy Sci. 77:3410-3416.

Robertson, J. B., and P. J. Van Soest. 1981. The detergent system of analysis and its application to human food. Page 123 in The Analysis of Dietary Fiber. W. P. T. James and O. Theander, ed. Marcel Dekker, New York, NY.

SAS/STAT. 1996. Software: Changes and Enhancements Through Release 6.11. SAS Inst., Inc., Cary, NC.

Smith, N. E., L. S. Collar, D. L. Bath, W. L. Dunkley, and A. A Franke. 1981. Digestibility and effects of whole cottonseed fed to lactating cows. J. Dairy Sci. 64:2209-2215.

Sullivan, H. M., J. K. Bernard, H. E. Amos, and T. C. Jenkins. 2004. Performance of lactating dairy cows fed whole cottonseed with elevated concentrations of free fatty acids in the oil. J. Dairy Sci. 87:665-671.

Zinn, R. E., and F. N. Owens. 1986. A rapid procedure for purine measurement and its use for estimating net ruminal protein syntheses. Can. J. Anim. Sci. 66:157-166. 